\title{
Fish remains from the Lower Cretaceous (Valanginian-Hauterivian) of Hárskút (Hungary, Bakony Mts)
}

\author{
Márton SzABó ${ }^{1,2}$ \\ ${ }^{1}$ Department of Palaeontology, Eötvös Loránd University, \\ H-1117 Budapest, Pázmány Péter sétány 1/C, Hungary; \\ ${ }^{2}$ Department of Palaeontology and Geology, Hungarian Natural History Museum, \\ H-1083 Budapest, Ludovika tér 2, Hungary.E-mailszabo.marton.pisces@gmail.com
}

\begin{abstract}
Lower Cretaceous (Valanginian-Hauterivian) fish remains, collected in the Közöskút Ravine (nearby Hárskút, Hungary) in the 1960s are detailed here. Although the material is poorly preserved, it is of great importance, because this geographical region and stratigraphical provenance are relatively undersampled for marine vertebrates. The collected material includes four orders of fish: Hexanchiformes, Synechodontiformes, Semionotiformes and Pycnodontiformes. This is the first, actualized report of some of the Hárskút fish taxa from the Mesozoic of Hungary. The results add important data to the distribution of the identified taxa, especially to that of Gyrodus. With 20 figures and 1 table.
\end{abstract}

Key words - Gyrodus, Hauterivian, Hárskút, Hexanchidae, Lepidotes, Sphenodus, Valanginian

\section{INTRODUCTION}

Our knowledge on the Mesozoic marine fishes of the Pannonian Basin is yet incomplete. Only a few papers describe these faunas (or faunal elements) in detail (e.g., Ösi et al. 2013, 2016; PÁszti 2004; SzABó et al. 2016a, b; SzABó \& Ösi 2017), while further works mention Mesozoic fish remains shortly (e.g., DULAI et al. 1992; FöZY \& SZENTE 2014). A large amount of Mesozoic fish remains were collected in the last century, however, most of them were found during excavations after invertebrate faunas.

Field works, carried out in the 1960s in the outcrop of the Közöskút Ravine near Hárskút (Hungary, Bakony Mts) yielded a few tooth remains of various chondrichthyans and osteichthyans. The locality was first described by FüLöP (1964) as an important locality for Early Cretaceous fossils. Later on, the outcrop and the collected invertebrate fauna was re-investigated by FözY et al. (2010). Among the Hárskút fish fossils, collected in 1960-1962, FüLÖP (1964) figured only a tooth of Sphenodus sp., and listed a tooth of Sphaerodus neocomiensis (see 
below). Fözy et al. (2010) also mentions ,isolated teeth of pycnodont and cartilaginous fishes", but aside from these, the collected vertebrate material remained unpublished.

Up to date, some of the collected Hárskút fish taxa have not been reported from the Pannonian Basin; however, their regional occurrence in the Lower Cretaceous is not necessarily surprising. The collected fish fauna includes two shark and two bony fish forms, representing different trophic groups. To alleviate the aforementioned incompleteness of our knowledge on the Lower Cretaceous fish faunas of Hungary, here I describe the re-discovered material in detail.

\section{LOCALITY AND GEOLOGICAL BACKGROUND}

The studied outcrop, named Közöskút Ravine (geographical coordinates: $47^{\circ} 9^{\prime} 58.17^{\prime \prime} \mathrm{N}, 17^{\circ} 47^{\prime} 11.48^{\prime \prime} \mathrm{E}$ ) is situated about $2.5 \mathrm{~km}$ E-SE from the village of Hárskút (southwestern part of the central Bakony Mts, Hungary) (Figs 1-3). During the last decades different sections of the Mesozoic succession of the Közöskút Ravine were sampled. Among them, the present study concentrates to the one, referred to as section HK-12, Közöskút Ravine at Hárskút. This section could be easily mistaken for an other nearby section, originally labelled as Hárskút 12/a (see Fözy et al. 2010 and Fözy 1990).

The HK-12 section exposes 28 metres of Lower Cretaceous pelagic carbonates. The ravine provides Lower to Middle Jurassic Rosso Ammonitico-type suc-
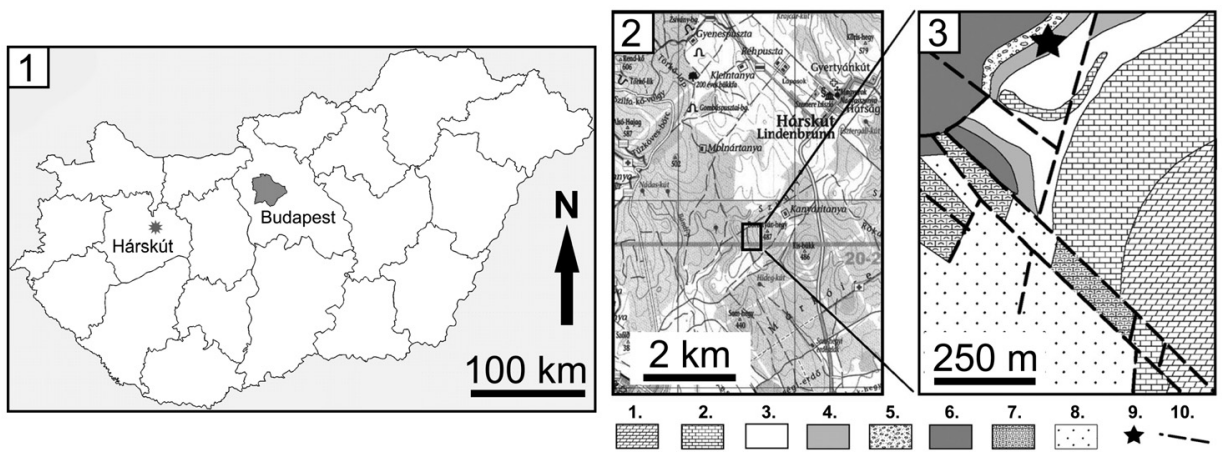

Figs 1-2. Geographical position of the HK-12 section (Hárskút) (Fig 2. modified after Fözy et al. 2010). - Fig. 3. Simplified geological map of the vicinitiy of the studied section. $-1=$ Triassic Dachstein Limestone. -2 = Lower and Middle Jurassic carbonates. $-3=$ Upper Jurassic cephalopod limestone. $-4=$ Lower Cretaceous Biancone-type carbonate. $-5=$ Lower Cretaceous cephalopod marl. $-6=$ Aptian crinoidal limestone. $-7=$ Post-Aptian carbonates. $-8=$ Tertiary deposits. $-9=$ Location of the section HK-12. $-10=$ Detected or supposed faults (modified after

Fözy et al. 2010) 
cession with repeated gaps, as the result of non-deposition (FÜLöP et al. 1969; GALÁCZ 1975). The Upper Jurassic is represented by the Lókút Radiolarite Formation and the overlying Pálihálás Limestone Formation. The Pálihálás Limestone passes upwards into the Upper Tithonian-Berriasian Szentivánhegy Limestone Formation. This is followed by the Biancone-type cherty marls of the Valanginian Mogyorósdomb Limestone Formation. The youngest Mesozoic formations, exposed in the HK-12 section are the uppermost Hauterivian cephalopod-bearing marl and the Aptian beds of the Tata Limestone Formation (Fözy et al. 2010) (Fig. 4).

The Berriasian beds of the section (beds 45-13) yielded a moderately diverse cephalopod fauna, including the zonal index species for the Tirnovella occitanica and Fauriella boissieri Zones, representing the Middle and Upper Berriasian. Beds 12-10 yielded a rich Early Valanginian ammonite fauna (beds 12, 11: Thurmanniceras pertransiens Zone; bed 10: Busnardoites campylotoxus Zone), while beds 9-1 are assigned to the early Late Valanginian (Saynoceras verrucosum Zone) (for field photographs see Figs 5-6). According to its rich ammonite fauna, a marl pit at the top of section HK-12 most probably represents the latest Hauterivian (FőzY et al. 2010). The latter assemblage was assigned to the Barremian by FüLÖP (1964), however, during their revision, FözY et al. (2010) did not recognize any typical early Barremian ammonite form listed by Fülöp.

\section{MATERIAL AND METHODS}

All here described fish remains were collected in the 1960s, during field work collection supervised by József Fülöp. The specimens were originally housed in the collection of the Mining and Geological Survey of Hungary (MBFSZ; Geological and Geophysical Institute of Hungary by earlier name). The material had been forgotten for decades, then it was re-discovered by István Fözy.

Altogether 11 fish teeth were collected from the Valanginian-Hauterivian formations of the Közöskút Ravine. The Valanginian Mogyorósdomb Limestone Formation yielded most of the fish teeth ( 9 teeth), while only two teeth came from the Hauterivian cephalopod-bearing marl at the top of the section. No Berriasian beds of the Közöskút Ravine yielded any vertebrate remain (Table 1).

All fish teeth are greyish to brownish in colour. All shark teeth are rootless, the preserved crowns are often damaged. The two bony fish teeth have nicely preserved crowns. Most teeth are still embedded in a piece of limestone-matrix, from which they are too risky to prepare without break/damage. The specimens were cleaned in tap water, no other chemical or mechanical method for preparation or conservation has been used. 


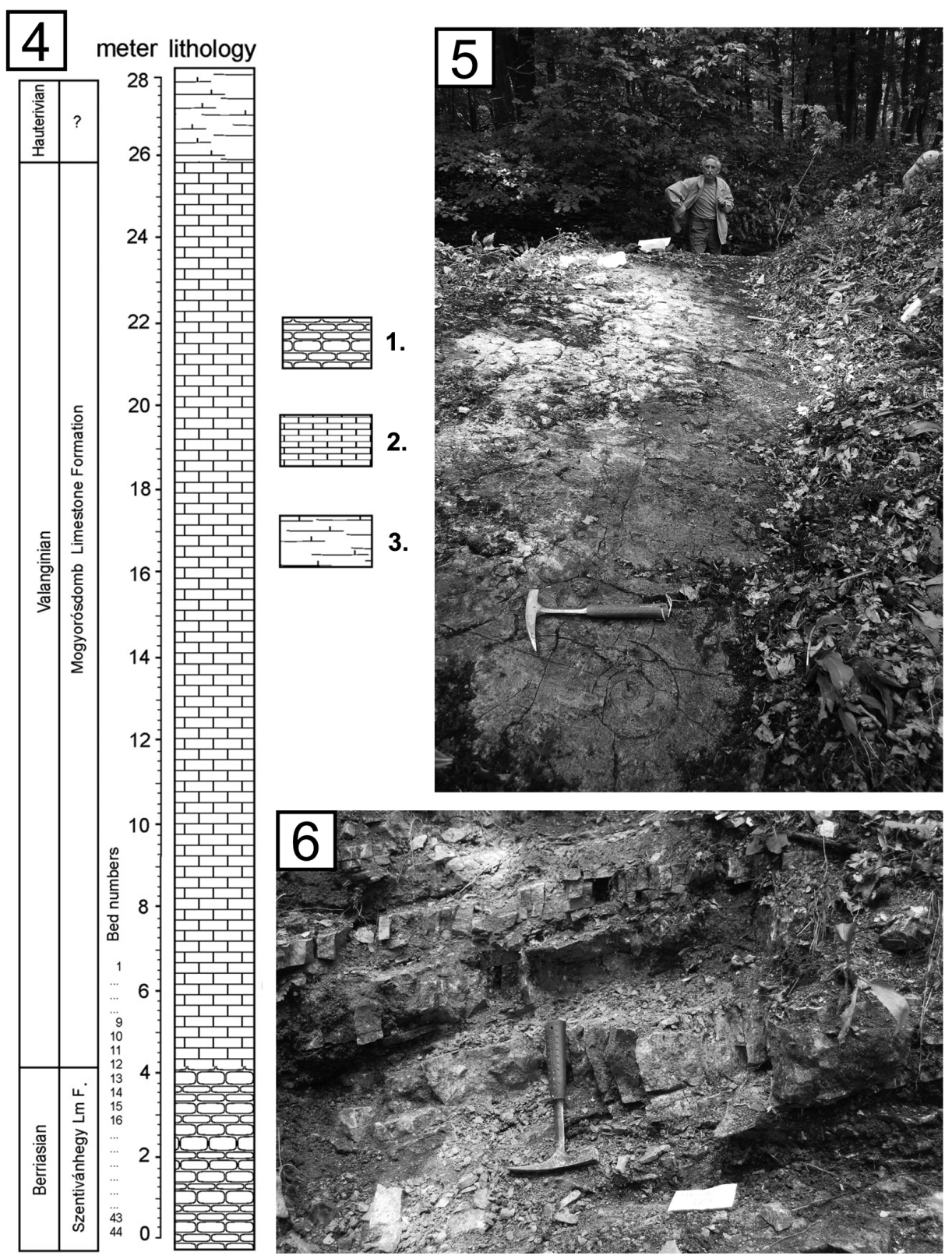

Fig. 4. Composite log of the HK-12 section. $-1=$ Rosso Ammonitico-type limestone. $-2=$ Biancone-type carbonate. -3 = grey marl (modified after FözY et al. 2010). - Fig. 5. Surface of bed 10 (photo courtesy of István Főzy). - Fig. 6. Marly limestone and clay above bed 10 (photo courtesy of István Főzy) 
Table 1: Distribution of the fish taxa in the Berriasian-Hauterivian beds of the HK-12 section

\begin{tabular}{|c|c|c|c|c|c|}
\hline & \multirow[t]{2}{*}{ Berriasian } & \multicolumn{3}{|c|}{ Valanginian } & \multirow[t]{2}{*}{ Hauterivian } \\
\hline & & bed 8 & bed 9 & bed 10 & \\
\hline Hexanchidae indet. & & $\mathrm{X}$ & & & \\
\hline Sphenodus sp. & & & & $\mathrm{X}$ & $\mathrm{X}$ \\
\hline Lepidotes sp. & & & & & $\mathrm{X}$ \\
\hline Gyrodus sp. & & & $\mathrm{X}$ & & \multirow{3}{*}{2} \\
\hline \multirow{2}{*}{ Number of teeth } & \multirow{2}{*}{0} & 1 & 1 & 7 & \\
\hline & & & 9 & & \\
\hline
\end{tabular}

\section{SYSTEMATIC PALAEONTOLOGY}

Class Chondrichthyes Huxley, 1880

Subclass Elasmobranchii Bonaparte, 1838

Cohort Euselachii Hay, 1902

Subcohort Neoselachii Compagno, 1977

Superorder Selachimorpha Nelson, 1984

Order Hexanchiformes Buen, 1926

Family Hexanchidae Gray, 1851

Hexanchidae indet.

(Figs 7-8)

Referred material - 1 lower tooth (MBFSZ 2017.237.1.); stratigraphic origin: Valanginian (HK-12/8).

Description - Only the crown is preserved, the full root is missing. The crown is embedded in a small piece of limestone, where it is displayed in lingual aspect. The preserved crown seems to be incomplete both mesially and distally; therefore the exact number of the mesial and distal cusplets can not be given. The crown is mesiodistally long, while apicobasally low, which refers to a possible lower tooth. Two, distally curved mesial cusplets are preserved. They distally increase in size, the mesial cutting edge of the first mesial cusplet is straight, while that of the second one is convex. The distal cutting edge of both mesial cusplets is weakly convex. The main cusp and the two distal cusplets are distally inclined, they show a characteristic, sigmoid contour (see on Fig. 8). This sigmoidism is given by the asymmetric convexity of their mesial cutting edge, and the weak convexity of their distal cutting edge. The preserved mesial and distal cusplets are nearly equal in size; however, the mesials are still smaller. 
Remarks - Family Hexanchidae is the most abundant hexanchoid family, ranges from the Mesozoic to the Recent (CAPpetTa 2012). The Hárskút hexanchid specimen is reminiscent of the teeth of Notidanodon, a hexanchid genus, which was also present in the Lower Cretaceous (CAPPETTA 2012; MutTERLOSE 1984; ThIEs 1987; WARD \& ThIEs 1987), however, since the tooth is too poorly preserved, here I describe it only as Hexanchidae indet.

\section{Order Synechodontiformes Duffin et Ward, 1993 \\ Family Orthacodontidae Glikman, 1957 \\ Genus Sphenodus Agassiz, 1843 \\ Sphenodus sp.}

(Figs 9-15)

Referred material - 8 teeth (MBFSZ 2017.238.1. - MBFSZ 2017.245.1.); stratigraphic origin: Valanginian (HK-12/10) and Hauterivian (Barremian in FüLÖP 1964).

Description - All here referred teeth are rootless. They are slender, pointed at the tip with smooth labial and lingual face. Both the labial and lingual faces are convex, which convexity is more expressed on the lingual side. The cutting edges are sharp on both sides of the crown. Following their upright crown, convex on both faces, the best preserved specimens may represent anterior teeth (distal teeth have more flattened, distally inclined crown).

Remarks - Here I follow KLUG (2010), who included Sphenodus in Synechodontiformes. The genus represents a group of pelagic predatory neoselachians. Numerous species of Sphenodus have been described (DUfFin \& WARD 1993), several of which have later been regarded as synonymous and/or nomina dubia (see KRIWET et al. 2006).

Only complete teeth allow a specific description (CAPpetTa 2012). Because of their poor preservation, the torsion and height of the Hárskút cusps (important features for specific identification; see BöTTCHER \& DUFFIN 2000, Table 1) are not investigeable. Therefore, following the low number and poor preservation of the Hárskút orthacodontid teeth here I describe them only as Sphenodus sp. Teeth of $S$. nitidus, a species reported from the Upper Jurassic and the Lower Cretaceous bear a distal cutting edge developed at the tip of the cusp only (BötTCher \& Duffin 2000, Table 1; see also Kanno et al. 2017, Table 1), which character is absent in the Hárskút specimens.

FülöP (1964, pl. 17, fig. 10) illustrated specimen MBFSZ 2017.245.1. as Odontaspis sp. The general crown morphology of Sphenodus and numerous odontaspids is very similar, which may have led Fülöp to the misidentification. 
Class Osteichthyes Huxley, 1880

Subclass Actinopterygii Cope, 1887

Division Holostei Müller, 1844

Order Semionotiformes Arambourg et Bertin, 1958

Family Semionotidae Woodward, 1890

Genus Lepidotes Agassiz, 1832

Lepidotes sp.

(Figs 16-17)

Referred material - 1 tooth (MBFSZ 2017.246.1.), stratigraphical origin: Hauterivian (Barremian in FÜLÖP 1964).

Description - The tooth is large and circular in occlusal view. The profile view is hemispherical, a worn, large central protuberance (or central papilla) is present, which is more visible in this view. The enamel is thick and shiny, it bears various signs of wear. The tooth base bears fine apicobasal ridges all around. This tooth remain was listed as Sphaerodus neocomiensis by FüLÖP (1964, p. 55).

Remarks - Almost any large, robust crushing tooth from the Mesozoic may be identified erroneously as Lepidotes sp. (FOREY et al. 2011). Isolated teeth of Lepidotes lack distinguishing characters, which often makes it difficult to differentiate them from related taxa (NORDÉN et al. 2015). The Hárskút specimen has very general characteristics, however, it still shows close morphological affinities with the teeth of the fish described widely as Lepidotes maximus (see e.g., Etheridge \& Willett 1889, pl. 15; Jain 1984, pl. 2, fig. C; Schneider $e t$ al. 2013, fig. 8F). Numerous nominal species of Lepidotes have been described, a part of them probably represents nomina dubia, and indeed the genus requires an exhaustive revision.

A similar tooth, found in the Barremian of Zirc, was figured by FüLÖP (1964, pl. 29, figs 9, 10) as Sphaerodus neocomiensis. Sphaerodus is a widely used, early synonym name for Lepidotes. The Zirc tooth may represents an other tooth remain of Lepidotes, based on its simple morphology of hemispherical shape and the presence of a central protuberance on the occlusal surface.

Division Halecostomi Regan, 1923

Order Pycnodontiformes Berg, 1937

Family Gyrodontidae Berg, 1940

Genus Gyrodus Agassiz, 1833

Gyrodus sp.

(Figs 18-20) 

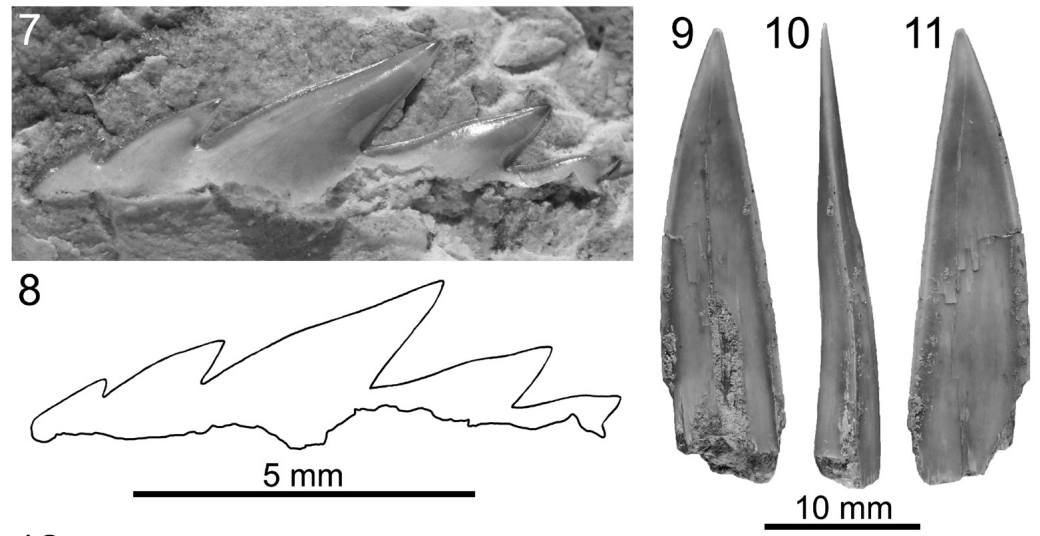

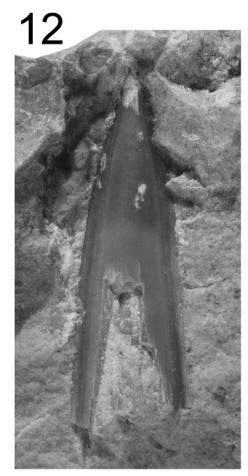

$5 \mathrm{~mm}$

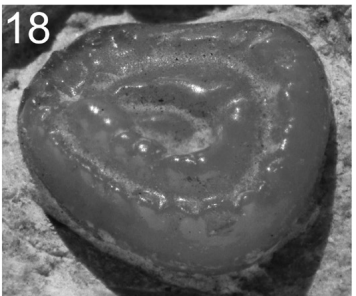

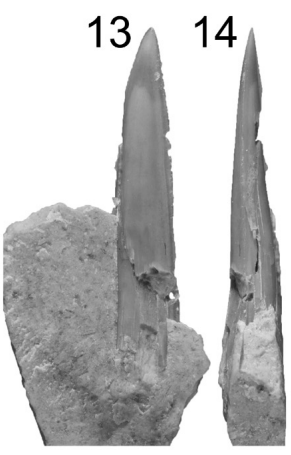

$10 \mathrm{~mm}$

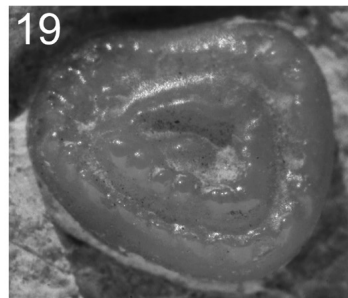

$3 \mathrm{~mm}$

Figs 7-8. Hexanchidae indet. lower tooth (MBFSZ 2017.237.1.) from bed HK-12/8 (Valanginian). - 7. Lingual view. - 8. Line drawing of the same specimen, for showing the sigmoidity of the acrocone and accessory conules. - Figs 9-11. Sphenodus sp. (MBFSZ 2017.245.1.) from the uppermost (Hauterivian) part of the HK-12 section. - 9. Lingual view. - 10. Profile view. - 11. Labial view. - Fig. 12. Sphenodus sp. tooth (MBFSZ 2017.238.1.) from bed HK-12/10 (Valanginian), ?lingual view. - Figs 13-15. Sphenodus sp. tooth (MBFSZ 2017.241.1.) from bed HK-12/10 (Valanginian). - 13. Lingual view. - 14. Profile view. - 15. Labial view. - Figs 16-17. Lepidotes sp. tooth (MBFSZ 2017.246.1.) from the uppermost (Hauterivian) part of the HK-12 section. - 16. Profile view. - 17. Occlusal view. - Figs 18-20. Gyrodus sp. tooth (MBFSZ 2017.247.1.) from bed HK-12/9 (Valanginian), in three different views showing the occlusal surface 
Referred material - 1 tooth (MBFSZ 2017.247.1.); stratigraphical origin: Valanginian (HK-12/9).

Description - The tooth remain is embedded in a piece of stone-matrix, exposed in occlusal aspect. The tooth is flattened, and has a pear to trapezoid shape in occlusal view. A well-marked central tubercle (or central papilla) is present, which is surrounded by an apical ring, running all around the central papilla, covered by crenulations. Near the occlusal margin, a second apical ring is present, also bearing roundish crenulations. In profile view, the inner apical ring is apicobasally higher, than the outer, larger one. Following these features, the tooth is unambiguously referred to the genus Gyrodus. Based on the preserved characters it can not be determined whether the tooth belonged to the vomerine or the prearticular dentition.

Remarks - Gyrodus ranges from the Middle Jurassic to the Early Cretaceous. The genus includes 32 species, among them two, G. hexagonus and G. circularis were based on more than isolated remains, including articulated skeletons (KRIWET \& SCHMITz 2005). The Early Cretaceous reports of the genus are rare and questionable. $G$. atherfieldensis from the Aptian of England is characterized by smooth teeth (possible result of wear or abrasion). When unworn, teeth of G. minor (Aptian of England), G. contiguidens (Hauterivian of France) and G. sculptus (Neocomian of France) exhibit an ornamentation similar to that of other Gyrodus species (KRIWET \& SCHMITz 2005 and references therein). The attribution of a dental remain described as G. ellipticus remains arguable, since it displays similarities with Coelodus and Ocloedus (after KRIWET \& SCHMITZ 2005). Isolated, sculptured pycnodont teeth from the Valanginian of France were assigned to genus Gyrodus by PiCtet et al. (1858-60).

Since only one Hárskút fish tooth is assigned to Gyrodus, due to the high variancy of the pycnodontiform dentition, I do not attempt to describe it closer than genus rank. A high similarity to the teeth of $G$. hexagonus is recognized (see KRIWET 2005, fig. 30C, D), however, G. hexagonus is resricted to the Jurassic (Kriwet 2005; Poyato-Ariza \& Wenz 2002).

\section{DISCUSSION}

The habitat preferences of the HK-12 fish taxa are in accordance with that of the collected invertebrate fauna, which includes both pelagic (ammonites, belemnites, rare nautiloids) and benthic (brachiopods, crinoids, echinoderms, etc.) faunal elements. Since the palaeogeographical position of Hárskút is given in a pelagic basin (Fözy et al. 2010), the partial or full pelagic lifestyle among the Hárskút fish forms is no surprise. 
The fossil record of Hexanchiformes (cow sharks) is dominated by isolated tooth remains, although articulated skeletal remains are also known (KRIWET \& KLUG 2011 and references therein). Mesozoic hexanchiform remains are rather rare, only a few hexanchiform teeth, found in the Mesozoic of Hungary are known in Hungarian natural history collections (SzABó in prep.). Extant hexanchiforms are dominantly demersal to pelagic sharks, modern members of family Hexanchidae generally prefer rather deep waters at more than one hundred metres (CAPPETTA 2012).

The dominant selachian form of the Mogyorósdomb Formation is Sphenodus (represented by 7 teeth). The tearing-type dentition of Sphenodus implies a diet of cephalopods and fishes, which together with the general body shape (similar to that of carcharhiniform sharks) refers Sphenodus as an active pelagic predator (CAPpetta 2012; Rees 2012; Thies \& Reif 1985), but according to UnderWood et al. (1999), it is unlikely that these sharks were rapid pursuit hunters. The quantitative dominance of Sphenodus is may related to the rich invertebrate fauna of the Mogyorósdomb Limestone, however, the presence of a large amount of smaller prey fishes is supposed. HeNNIG (1914) suggested that Sphenodus was a scavenger, because its teeth often co-occur with disarticulated vertebrate remains.

Species of the non-teleostean neopterygian Lepidotes are widely considered as durophagous predators with nektonic habits (e.g., POYATO-ArIzA 2005; database of fossilworks.org). The presence of Lepidotes in the Hauterivian of the HK-12 section is might connected to the rich cephalopod fauna. By their strong, crushing dentition, semionotid fishes could be considered as possible predators of ammonites (see e.g., MARTILL 1990).

The distribution of Gyrodus implies that members of the genus were not only living in near-coastal habitats (where they found most of their food), but they also had a pelagic lifestyle, which enabled Gyrodus to cross deeper sea basins (Kriwet \& Schmitz 2005). Pycnodontiform fishes are known from various localities of Hungary, such as Iharkút (Santonian; SzABó et al. 2016b), Ajka (Santonian; Ösı et al. 2016) and Sümeg (Campanian; mentioned in FöZY \& SZEnte 2014). PÁszti (2004) reported pycnodontiform fishes from the Lower Jurassic (Toarcian) Úrkút Manganese Ore Formation; however, the published specimens clearly represent other taxa (personal observation).

Unlike Gyrodus, Sphenodus and Lepidotes are common in most Mesozoic marine deposits around the world. Following the available data, genus Gyrodus seems to be restricted to Europe in the Early Cretaceous. The occurrence of this pycnodontiform in the Lower Cretaceous of Hárskút adds important data to our knowledge on its distribution patterns. 


\section{CONCLUSIONS}

The pelagic Lower Cretaceous formations of the HK-12 section of the Közöskút Ravine yielded various fish remains. The presence of the demersal-pelagic hexanchids, the pelagic Sphenodus and the coastal-pelagic Gyrodus is more or less evident, while the occurrence of the nektonic semionotiform Lepidotes may be attributed to trophic reasons. Sphenodus and Lepidotes are widely reported from numerous localities around Europe. The present study provides the first report of Gyrodus from the Pannonian Basin. Further occurrence of more, rare Mesozoic fish taxa is expected in natural history collections of Hungary.

Acknowledgements - I thank the anonymous reviewer for his constructive comments and suggestions that greatly improved an earlier version of the manuscript. I am grateful to István Fözy for providing many useful information and photographs about the studied area. László Makádi and Klára Palotás (Mining and Geological Survey of Hungary) are thanked for helping in inventorying the specimens. The online database of Fossilworks (fossilworks.org) is also acknowledged here. My work was supported by the National Research, Development and Innovation Office (K116665), the Hungarian Natural History Museum, the Eötvös Loránd University and the ELTE Dinosaur Research Group.

\section{REFERENCES}

BötTCHER R. \& DUfFin C.J. 2000: The neoselachian shark Sphenodus from the Late Kimmeridgian (Late Jurassic) of Nusplingen and Egesheim (Baden-Württemberg, Germany). - Stuttgarter Beiträge zur Naturkunde, serie B 283: 1-31.

Cappetta H. 2012: Handbook of Paleoichthyology, Vol. 3E: Chondrichthyes. Mesozoic and Cenozoic Elasmobranchii: Teeth. - Verlag Dr. Friedrich Pfeil, 512 pp.

DUfFIN C. J. \& WARD D. J. 1993: The Early Jurassic palaeospinacid sharks of Lyme Regis, southern England. - Belgian Geological Survey, Professional Paper: Elasmobranches et stratigraphie 264: 53-101.

Dulai A., Suba Zs. \& Szarka A. 1992: Toarci (alsójura) szervesanyagdús fekete pala a mecseki Réka-völgyben. (Toarcian (Lower Jurassic) organic-rich black shale in the Réka Valley (Mecsek Hills, Hungary)). - Földtani Közlöny 122(1): 67-87. (in Hungarian with English abstract)

ETHERIDGE M. R. \& Willett H. 1889: On the dentition of Lepidotus maximus, Wagner, as illustrated by specimens from the Kimeridge Clay of Shutover Hill, near Oxford. - Quarterly Journal of the Geological Society 45: 356-358.

Forey P. L., López-Arbarello A. \& MacLeod N. 2011: A New Species of Lepidotes (Actinopterygii: Semiontiformes) from the Cenomanian (Upper Cretaceous) of Morocco. - Palaeontologia Electronica 14(1) 7A: $12 \mathrm{pp}$.

Fözy I. 1990: Ammonite succession from three upper Jurassic sections in the Bakony Mts. (Hungary). - In: Pallini et al. (eds): Atti del secondo convegno internazionale Fossili, Evoluzione, Ambiente, Comitato Centenario Raffaele Piccinini, Pergola, pp. 323-329. 
FöZy I. \& SZente I. 2014: Fossils of the Carpathian Region. - Indiana University Press, 508 pp.

Fözy I., Janssen N. M. M., Price G., Knauer J. \& PÁlfy J. 2010: Integrated isotope and biostratigraphy of a Lower Cretaceous section from the Bakony Mountains (Transdanubian Range, Hungary): A new Tethyan record of the Weissert event. - Cretaceous Research 31: 525-545. http://dx.doi.org/10.1016/j.cretres.2010.07.003

FÜLöP J. 1964: A Bakonyhegység alsó-kréta (berriázi-apti) képződményei. (Lower Cretaceous (Berriasian-Aptian) formations in the Bakony Mountains). - Geologica Hungarica, Series Geologica 13: 1-193.

FÜLÖP J., GÉCZY B., KondA J. \& NAGY E. 1969: Földtani kirándulás a Mecsek hegységben, a Villányi-hegységben és a Dunántúli-középhegységben. [Geological field trips in the Mecsek Mountains, in the Villány Mountains and in the Transdanubian Mountains.] - Mediterrán Jura Kollokvium, Budapest 1969, Hungarian Geological Institute, Budapest, pp. 1-68. (in Hungarian)

GALÁCz A. 1975: Bajóci szelvények az Északi Bakonyból. (Bajocian sections from the northern Bakony Mts.) - Földtani Közlöny 105: 208-219. (in Hungarian with English abstract)

Hennig E. 1914: Die Fischreste unter den Funden der Tengaguru-Expedition. - Archiv für Biontologie 3: 293-312.

JAIN S. L. 1984: Some new observations on Lepidotes maximus (Holostei: Semionotiformes) from the German Upper Jurassic. - Journal of the Paleontological Society of India 30: 18-25.

Kanno S., Nakajima Y., Hikida Y. \& Sato T. 2017: Sphenodus (Chondrichthyes, Neoselachii) from the Upper Cretaceous in Nakagawa Town, Hokkaido, Japan. - Paleontological Research 21(2): 122-130. http://dx.doi.org/10.2517/2016PR009

KLUG S. 2010: Monophyly, phylogeny and systematic position of the Synechodontiformes (Chondrichthyes, Neoselachii). - Zoologica Scripta 39: 37-49.

http://dx.doi.org/10.1111/j.1463-6409.2009.00399.x

KRIWET J. 2005: A comprehensive study of the skull and dentition of pycnodont fishes. - Zitteliana 45: $135-188$.

Kriwet J. \& Klug S. 2011: A new Jurassic cow shark (Chondrichthyes, Hexanchiformes) with comments on Jurassic hexanchiform systematics. - Swiss Journal of Geosciences 104(1): 107114. http://dx.doi.org/10.1007/s00015-011-0075-z

Kriwet J., Lirio J. M., NuÑez H. J., Puceart E. \& LéCuyer C. 2006: Late Cretaceous Antarctic fish diversity. - In: Pirrie D., Francis J. E. \& Crame J. A. (eds): Cretaceous-Tertiary HighLatitude Palaeoenvironments, James Ross Basin, Antarctica. - Geological Society, London, Special Publication 258: 83-100. http://dx.doi.org/10.1144/GSL.SP.2006.258.01.01

KRIWET J. \& SCHMitz L. 2005: New insight into the distribution and palaeobiology of the pycnodont fish Gyrodus. - Acta Palaeontologica Polonica 50: 49-56.

Martill D. M. 1990: Predation on Kosmoceras by semionotid fish in the Middle Jurassic Lower Oxford Clay of England. - Palaeontology 33(3): 739-742.

Mutterlose J. 1984: Die Unterkreide-Aufschlüsse (Valangin-Alb) im Raum Hannover-Braunschweig. - Mitteilungen aus dem Geologischen Institut der Universität Hannover 24: 1-61.

Nordén K. K., Duffin C. J. \& Benton M. J. 2015: A marine vertebrate fauna from the Late Triassic of Somerset, and a review of British placodonts. - Proceedings of the Geologists' Association 126: 564-581. http://dx.doi.org/10.1016/j.pgeola.2015.07.001

Ösi A., Bodor E., MAKÁDi L. \& RABI M. 2016: Vertebrate remains from the Upper Cretaceous (Santonian) Ajka Coal Formation, western Hungary. - Cretaceous Research 57: 228-238. http://dx.doi.org/10.1016/j.cretres.2015.04.014

Ösi A., Botfalvai G., Prondvai E., Hajdu Zs., Czirják G., Szentesi Z., Pozsgai E., Götz A. E., MAKÁDI L., CsENGődi D. \& SEBE K. 2013: First report of Triassic vertebrate assemblages 
from the Villány Hills (Southern Hungary). - Central European Geology 56(4): 297-335. http://dx.doi.org/10.1556/CEuGeol.56.2013.4.2

PÁszTi A. 2004: Halmaradványok az Úrkúti Mangánérc Formáció képződményeiből. (Fish remains from the Úrkút Manganese Ore Formation). - Bányászati és Kohászati Lapok - Bányászat 137(6): 46-47. (in Hungarian with English abstract)

Pictet F.-J., Campiche G. \& Tribolet G. De 1858-60: Description des fossiles du terrain Crétacé des environs de Sainte-Croix. - Première Partie, 380 pp.

Poyato-Ariza F. J. 2005: Palaeoecology of the fishes from the Early Cretaceous lake of Las Hoyas, Cuenca, Spain, with a hypothesis of sexual dimorphism for the Chanidae Rubiesichthys. Bulletin of the Kitakyushu Museum of Natural History and Human History Series A3: 153-168.

Poyato-Ariza F. J. \& Wenz S. 2002: A new insight into pycnodontiform fishes. - Geodiversitas 24: $139-248$.

REES J. 2012: Palaeoecological implications of neoselachian shark teeth from the Bathonian (Middle Jurassic) ore-bearing clays at Gnaszyn, Kraków-Silesia Homocline, Poland. - Acta Geologica Polonica 62(3): 397-402.

Schneider S., Harzhauser M., Kroh A., Lukeneder A. \& Zuschin M. 2013: Ernstbrunn Limestone and Klentnice beds (Kimmeridgian-Berriasian; Waschberg-Ždánice Unit; NE Austria and SE Czech Republic): state of the art and bibliography. - Bulletin of Geosciences 88(1): 105-130. http://dx.doi.org/10.3140/bull.geosci.1360

Szabó M., GulYás P. \& Ösı A. 2016a: Late Cretaceous (Santonian) Atractosteus (Actinopterygii, Lepisosteidae) remains from Hungary (Iharkút, Bakony Mountains). - Cretaceous Research 60: 239-252. http://dx.doi.org/10.1016/j.cretres.2015.12.002

SZABó M., GulYÁs P. \& Ösı A. 2016b: Late Cretaceous (Santonian) pycnodontid (Actinopterygii, Pycnodontidae) remains from the freshwater deposits of the Csehbánya Formation, (Iharkút, Bakony Mountains, Hungary). - Annales de Paléontologie 102: 123-134. http://dx.doi.org/10.1016/j.annpal.2016.04.001

SzABó M. \& Ösı A. 2017: The continental fish fauna of the Late Cretaceous (Santonian) Iharkút locality (Bakony Mountains, Hungary). - Central European Geology 60(2): 230-287. http://dx.doi.org/10.1556/24.60.2017.009

THIEs D. 1987: Palaeoecology of Lower Cretaceous cow sharks (Neoselachii, Hexanchiformes). Paläontologische Zeitschrift 61(1/2): 133-140.

Thies D. \& Reif W.-E. 1985: Phylogeny and evolutionary ecology of Mesozoic Neoselachii. Neues Jahrbuch für Geologie und Paläontologie, Abhandlungen 169: 333-361.

Underwood C. J., Mitchell S. F. \& Welt Kamp K. J. 1999: Shark and ray teeth from the Hauterivian (Lower Cretaceous) of North-East England. - Palaeontology 42(2): 287-302.

Ward D. J. \& Thies D. 1987: Hexanchid shark teeth (Neoselachii, Vertebrata) from the Lower Cretaceous of Germany and England. - Mesozoic Research 1(2): 89-106. 